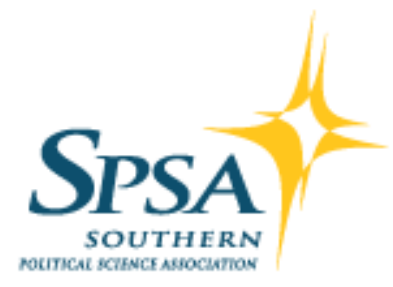

\title{
Policy Responsiveness to Protest-Group Demands
}

\section{Author(s): Paul D. Schumaker}

Source: The Journal of Politics, Vol. 37, No. 2 (May, 1975), pp. 488-521

Published by: The University of Chicago Press on behalf of the Southern Political Science Association

Stable URL: http://www.jstor.org/stable/2129004

Accessed: 07-05-2018 18:03 UTC

JSTOR is a not-for-profit service that helps scholars, researchers, and students discover, use, and build upon a wide range of content in a trusted digital archive. We use information technology and tools to increase productivity and facilitate new forms of scholarship. For more information about JSTOR, please contact support@jstor.org.

Your use of the JSTOR archive indicates your acceptance of the Terms \& Conditions of Use, available at http://about.jstor.org/terms 


\title{
Policy Responsiveness
}

\author{
to \\ Protest-Group \\ Demands
}

Paul D. Schumaker

$\mathrm{P}$

olrtical scientists have long been concerned with electoral activity and formal interest-group activity as methods of citizen participation linking public policy preferences to governmental outputs. $^{1}$ However, as a means of assuring that public policy corresponds to citizen preferences, both of these modes of participation have their limitations. For example, Verba and Nie argue that "voting can provide a lot of pressure on leaders (especially if

"This article is a revised version of a paper entitled "Urban Protest Groups: Explaining Successful Interactions with Public Authorities," presented at the annual meeting of the Western Political Science Association, Denver, Colo., April 4-6, 1974. I am grateful to Peter Eisinger, Charles Cnudde, Jean Schumaker, Russell Getter, Herman Lujan, and David Jones for their many helpful suggestions and their assistance in developing, researching, or reporting the concepts in this paper.

1 The literature on the policy effectiveness of electoral and interest-group participation is enormous. See Norman R. Luttbeg, ed., Public Opinion and Public Policy: Models of Political Linkage (rev. ed.; Homewood, Ill.: Dorsey Press, 1974), for many of the important recent articles in this area. Two major studies on these issues at the community level have appeared in recent years. See Sidney Verba and Norman Nie, Participation in America: Political Democracy and Social Equality (New York: Harper and Row, 1972); and Heinz Eulau and Kenneth Prewitt, Labyrinths of Democracy: Adaptions, Linkages, Representation, and Policies in Urban Politics (Indianapolis, Ind.: BobbsMerrill Company, 1973). 
they wish re-election) but it conveys little information per se on the preferences of the participants." 2 Participation through interest groups is a superior linkage mechanism in that it conveys much more specific information about citizen attitudes, but it has the deficiency that primarily well-educated, high-income citizens participate in interest groups. The result, as E. E. Schattschneider succinctly put it, is that "the heavenly chorus [of the interestgroup system] sings with a strong upper class accent."3

Given these limitations of both voting and formal interest-group activity, political scientists might profitably explore additional modes of participation and examine their adequacy as linkage mechanisms. In this respect, research by Gabriel Almond and Sidney Verba has shown that most citizens believe that their primary interests can best be communicated to political officials through informal issue-specific groups rather than through electoral activity or formal interest-group participation. According to Almond and Verba, when wishing to influence government, "respondents less frequently mention enlisting the support of formal groups than informal groups-arousing their neighbors, getting friends and acquaintances to support their position, circulating a petition." And particularly in the United States and Britain, "the use of informal groups is seen . . . as the key to effective protest." 5 However, as a limitation on the importance of such groups, they note that "the use of informal groups as a means of influencing a government decision is considered much more appropriate at the local than on the national level." 6

One of the tasks which Robert Dahl attempts to accomplish in Who Governs? is to demonstrate that this subjective belief in the effectiveness of informal group activity at the local level is well founded. To illustrate this point, Dahl describes the case of the metal houses where Miss Mary Grava and her neighbors in New Haven organized on an informal basis, protested, and attained the desired policy response from the New Haven political system. ${ }^{7}$

2 Participation in America, 322.

${ }^{3}$ The Semisovereign People (New York: Holt, Rinehart, and Winston, $1960), 35$.

${ }^{4}$ The Civic Culture (Boston: Little, Brown \& Co., 1965), 150.

5 Ibid., 157.

6 Ibid.

${ }^{7}$ Who Governs? (New Haven, Conn.: Yale University Press, 1961), 191200. 
Thus, citizens may frequently use informal group activity to convey their interests and demands to community authorities, and authorities may frequently be responsive. However, such informal group activity has received little systematic attention from political scientists. The reason for this inattention seems to be that informal group activity of the type described by Almond, Verba, and Dahl is clearly protest activity, but the concept of "protest" has in recent years acquired an overly restrictive meaning. For example, Michael Lipsky has argued that protest activity is "a mode of political action oriented toward objection of one or more policies or conditions, characterized by showmanship or display of an unconventional nature." Peter Eisinger writes that protest "is a device by which groups of people manipulate fear of disorder and violence while at the same time they protect themselves from paying the potentially extreme costs of acknowledging such a strategy." "9 These definitions equate protest activity with direct action tactics; the term "protest group" is reserved for those who use demonstrations, obstructions, boycotts, and other "unconventional" participation strategies. By focusing on groups employing such strategies, students of protest groups have ignored the more frequent activities of otherwise unorganized citizens who coalesce on an informal basis to influence public authorities through conventional strategies.

In order to correct the deficiency of focusing on the unconventional, the following definition of protest groups is offered. Protest groups are groups of citizens who do not normally interact with governmental officials, but who, under certain conditions (when they perceive that their interests are threatened by the activities of others or that the political system can be of use in furthering these interests) organize on an informal, issue-specific basis to make demands on public officials through pressure processes.

According to this definition, protest groups are not to be distinguished from groups employing conventional political strategies, for they can use either conventional or unconventional strategies. Instead, they are to be distinguished from traditional interest groups on grounds of regular access to authorities. ${ }^{10}$ Those groups whose

8 Protest in City Politics (Chicago: Rand McNally \& Company, 1970), 2.

9 "The Conditions of Protest Behavior in American Cities," American Political Science Review, 67 (March 1973), 14.

${ }^{10}$ See Schattschneider, Semisovereign People, 28-29, for a justification of this distinction. 
leaders have a high degree of continuous interaction with public officials are here labeled "interest groups." Those groups which do not continually interact with public officials but do so on an issue-specific basis are here labeled "protest groups." Normally those interest groups having regular access can be expected to have more abundant power resources (for example, professional leadership, financial well-being, legitimacy, and the like) than those protest groups lacking regular access. It is in this sense that protest groups are "relatively powerless." 11

Given this conception of protest groups, two questions immediately suggest themselves about the effectiveness of protest-group activity in local politics: (1) Are local political systems normally responsive to protest-group demands and activities? and (2) Under what conditions are local political systems most responsive to protest-group demands and activities?

Most political science research has been directed toward answering the first question. Pluralists have argued that citizens who organize themselves as informal protest groups can be effective; they have collected data which describe political systems as responsive to protest-group demands. ${ }^{12}$ Elite theorists have contended that informal protest groups are seldom effective; they have collected data which describe political systems as unresponsive to protest-group demands. ${ }^{13}$ Such studies appear to leave political science with little more than ideologically biased case studies.

Transcending the elite theorist and pluralist perspectives, it can be suggested that political officials in local communities are sometimes responsive, sometimes nonresponsive, and sometimes partially responsive to protest-group demands. A concern for theoretical explanation rather than simple description requires a search for

11 Lipsky, in Protest in City Politics, 2, has characterized protest groups as being "relatively powerless." However, the finding that protesters have a higher socio-economic status than nonprotesters has led to a denial of this claim. For a discussion of these notions, see Peter K. Eisinger, "Racial Differences in Protest Participation," American Political Science Review, 68 (June 1974), 596601.

12 Dahl's Who Governs? is the effective treatment of this viewpoint.

${ }^{13}$ See, for example, Michael Parenti, "Power and Pluralism: A View from the Bottom," Journal of Politics, 32 (August 1970), 501-530, and the essays in Race and Politics in New York City, ed. Jewell Bellush and Stephen M. David (New York: Praeger Publishers, Inc., 1971). 
those conditions or factors that result in communities being more or less responsive.

Some scholars have sought to specify variables affecting the probability that protest groups will receive favorable or unfavorable responses from political systems. ${ }^{14}$ Although helpful in many ways, their explanations have suffered several deficiencies. Some have been stated in very unsystematic and informal terms; explanatory variables are not drawn together and interrelated in a summary model. Thus such methodological possibilities as spuriousness and developmental sequences are ignored. Other explanations have considered a very limited set of explanatory variables; by ignoring the possible impact of variables suggested by other researchers, the development of cumulative evidence regarding the relative importance of various explanatory variables is retarded. In addition, most explanations, being empirically grounded in a few case studies, have met only primitive standards of verification. Nevertheless, the explanations offered by various analysts can be drawn together, stated systematically, and tested using a comparative data base. These are the objectives of this paper.

\section{A Model of Protest-Group Influence}

The degree of responsiveness by local political systems to protest-

14 The most important study in this regard is Lipsky's Protest in City Politics. However, other studies which seek to explain responsiveness include Bryan Downs and Kenneth Greene, "The Politics of Open Housing in Three Cities," American Politics Quarterly, 1 (April 1973), 215-243; Donald Von Eschen, Jerome Kirk, and Maurice Pinard, "The Conditions of Direct Action in a Democratic Society," Western Political Quarterly, 22 (June 1969), 309-325; Cornelis J. Lammers, "Strikes and Mutinies: A Comparative Study of Organization Conflicts Between Rulers and Ruled," Administrative Science Quarterly, 4 (December 1969), 558-572; Robert Crain et al., The Politics of School Desegregation (Garden City, N. Y.: Doubleday \& Co., 1969); James Q. Wilson, "The Strategy of Protest: Problems of Negro Civic Action," Journal of Conflict Resolution, 5 (September 1961), 291-303; Richard Lovak, "Urban Renewal Controversies," Public Administration Review, 32 (July/August 1972), 359373; and John H. Mollenkopf, "On the Causes and Consequences of Neighborhood Mobilization" (paper presented at the 69th annual meeting of the American Political Science Association, New Orleans, La., September 4-8, 1973). For a broad theoretical overview of the role of discontented groups in the political process, see William Gamson, Power and Discontent (Homewood, Ill.: Dorsey Press, Inc., 1968). 
group demands is the dependent variable in this study. The explanatory or independent variables are aspects of two constructs: (1) protester-controlled variables, and (2) the environment of social support. A schematic diagram showing the hypothesized linkages among these constructs as well as the types of variables used here is given in Figure 1.

\section{FiguRe 1}

Protester-controlled Variables, Soctal Support, and Responsiveness

\begin{tabular}{|c|c|c|}
\hline $\begin{array}{l}\text { Protester-controlled } \\
\text { Variables }\end{array}$ & Environment of & Responsiveness \\
\hline $\begin{array}{l}\text { Variables in this Study } \\
\text { Demand Dimensions } \\
\text { Zero-Sumness } \\
\text { Status-Welfare } \\
\text { Status quo/Change } \\
\text { Leadership Dimensions } \\
\text { Radicalness of Leaders } \\
\text { Presence of External Leaders } \\
\text { Organization Dimensions } \\
\text { Organizational Stability } \\
\text { Number of Active Members } \\
\text { Action Dimension } \\
\text { Unconventionality of Actions }\end{array}$ & $\begin{array}{l}\text { Variables } \\
\text { Degree of Support } \\
\text { or Hostility of the } \\
\text { following Sectors: } \\
\text { Agency Officials } \\
\text { Elected Officials } \\
\text { The Media } \\
\text { Active Groups } \\
\text { Community as } \\
\text { a Whole }\end{array}$ & $\begin{array}{l}\text { Variable } \\
\text { Policy Responsiveness }\end{array}$ \\
\hline
\end{tabular}

Before discussing general hypotheses, it is useful to define the basic concepts in the model. Because the concept of responsiveness has been particularly troublesome, it will be dealt with first. ${ }^{15}$ In

${ }^{15}$ In other contexts, the term "responsiveness" has taken on a number of divergent meanings. For example, Verba and Nie, in Participation in America, 299-304, define responsiveness as the degree to which community elites mirror the ideology, values, and attitudes of the inactive population. State policy analysts have conceptualized responsiveness as the degree to which public policy is congruent with public opinion. As an illustration, see Ronald Weber, Public Policy Preferences in the States (Bloomington: Institute for Public Administration, Indiana University, 1971). Kenneth Prewitt and Heinz Eulau define responsiveness in terms of the degree to which policy-makers look to their constituency for policy-making cues. See "Political Matrix and Political Representation: Prolegomenon to a New Departure for an Old Problem," American Political Science Review, 63 (June 1969), 427-441. 
this study, responsiveness is conceptualized as the relationship between the manifest or explicitly articulated demands of a protest group and the corresponding actions of the political system which is the target of the protest-group demands. In order to complete this definition of responsiveness, criteria must be formulated specifying the types of actions local systems must take in order to be considered responsive. After all, different persons have different standards for measuring the responsiveness of political systems. For example, some may suggest that giving a group a fair hearing constitutes responsive action. ${ }^{16}$ However, others argue that only those systems can be termed responsive which actually alleviate the grievances of protest groups by bringing about real changes in their living conditions. ${ }^{17}$

Five criteria of responsiveness can be suggested and the distinctiveness of each criterion illustrated by an example. Suppose that a protest group demands open housing legislation as a means of enhancing opportunities for inner city blacks. In response, authorities may first be willing to meet with protest-group leaders to discuss the possibility of enacting such legislation. The notion of "access responsiveness" indicates the extent to which authorities are willing to hear the concerns of such a group. ${ }^{18}$ Of course, granting access fails to indicate that authorities will make a serious effort to consider the demands. However, if the demand for open housing is made into an issue and placed on the agenda of the political system, there has occurred a second type of responsiveness which can here be labeled "agenda responsiveness." 19 As the proposal for open housing which is on the agenda is passed into law, a third type of responsiveness is attained; the notion of "policy responsiveness" indicates the degree to which those in the political system adopt legislation or policy congruent with the manifest demands of protest groups. Still, the passage of open housing legislation does

16 The notion that a "fair hearing" constitutes adequate responsiveness may frequently be embraced by protesters themselves. See Gamson, Power and Discontent, 51.

17 Lipsky, Protest in City Politics, 130-162.

18 This concept of access-responsiveness is similar to Eisinger's notion of "breeching the political opportunity structure." See "Conditions of Protest Behavior," 17.

${ }^{19}$ For a discussion of this idea, see Roger W. Cobb and Charles D. Elder, Participation in American Politics: The Dynamics of Agenda-Building (Boston: Allyn and Bacon, Inc., 1972). 
not ensure that such a policy will be effectively implemented; funds and personnel may not be allocated to enforce the legislation. But if measures are taken to ensure that the legislation is fully enforced, then a fourth type of responsiveness is attained; "output responsiveness" indicates the degree to which those in the political system implement policy-responsive actions. Yet, even fully implemented policies may not change the underlying condition which gave rise to the original demand. For a variety of reasons (for example, cultural considerations, financial considerations, and so on) very few blacks may take advantage of the open housing legislation by moving to predominantly white areas of the city. Only if the underlying grievance is alleviated would a fifth type of responsiveness be attained; "impact responsiveness" indicates the degree to which the actions of the political system succeed in alleviating the grievances of protest groups. ${ }^{20}$

In this paper only the intermediate standard of responsiveness, policy responsiveness, is examined. ${ }^{21}$ Because the adoption of responsive policies in no way guarantees that the underlying grievances of the protest group will be alleviated, it would of course be preferable to deal with the more rigorous standards of responsiveness. But to do so would create enormous problems of discovering and measuring the implementation and impact of policy responsive actions. Although estimating output responsiveness and impact responsiveness to protest-group demands may be feasible in case study research, the obstacles hindering the collection of these data make such a goal unattainable in a comparative study like this one. $^{22}$

The model in Figure 1 suggests that policy responsiveness is partially explained by protester-controlled variables and social support variables. Protester-controlled variables are defined as those fac-

${ }^{20}$ For a further discussion of the distinction between policy, output, and impact, see Sharkansky, "Environment, Policy, Output, and Impact" in Policy Analysis in Political Science, ed. Sharkansky (Chicago: Markham Publishing Co., 1970), 61-79.

21 Data on a less rigorous standard of responsiveness, access responsiveness, have been collected and analyzed, but because of space limitations are not reported here. These data are available in my "Urban Protest Groups: Explaining Successful Interactions with Public Authorities" (paper presented at the annual meeting of the Western Political Science Association, Denver, Colo., April 4-6, 1974.)

${ }^{22}$ For a discussion of measuring the gap between policy responsiveness and impact responsiveness, see Lipsky, Protest in City Politics, 85-162. 
tors which protest groups can directly manipulate or control. In other words, it is presumed that some freedom of choice concerning these variables is available to protest groups even though these choices are influenced by certain factors not considered in this analysis. It is this freedom of choice which enables protesters to manipulate their own behavior so as to enhance their effectiveness. In this respect, the previous literature has suggested that certain choices by protest groups regarding their demands, strategies, organizations, and leadership can influence their effectiveness. ${ }^{23}$ Therefore, the various aspects of these concepts listed in Figure 1 will be examined to determine their effects on policy responsiveness.

Social support, the second explanatory construct in Figure 1, refers to varying degrees of backing or antagonism that segments of the community afford protest groups and their demands. As aspects of this construct, five segments which may affect responsiveness are considered: (1) agency officials, (2) elected officials, (3) the media, (4) active groups in the community, and (5) the "community as a whole."24

In addition to conceptualizing social support as an independent variable affecting responsiveness, it is theoretically important to regard it as an intervening variable in a developmental sequence, as diagramed in Figure 1. As an intervening variable, social support may help interpret the relationships between protester-controlled

${ }^{23}$ The speculative and qualitative literature which links responsiveness to the nature of protest-group demands, organization, leadership, and strategies is enormous. See Schattschneider's discussion of the "mobilization of bias" against certain types of demands in Semisovereign People, 62-77. See Von Eschen et al., "Conditions of Direct Action," 319, for a discussion of the relationship between organizational size and responsiveness; and Saul Alinsky, Reveille for Radicals (New York: Random House, Vintage Books, 1969), 76131, for a discussion of the importance of organizational stability. However, Michael Lipsky and Margaret Levi present a different view of the utility of organizational stability in "Community Organization as a Political Resource," in People and Politics in Urban Society, ed. Harlan Hahn (Beverly Hills, Calif.: Sage Publications, 1972). See Everett Carll Ladd, Jr., Negro Political Leadership in the South (Ithaca, N. Y.: Cornell University Press, 1966), 145-232, for a discussion of the effects of leadership on responsiveness, and Amitai Etzioni, Demonstration Democracy (New York: Gordon \& Breach, 1970), and Wilson, "Strategy of Protest," for illustrative discussions of the impact of unconventional protest actions on responsiveness.

24 They are not intended to be exhaustive. Other sectors, such as the "community power structure," may be important. 
variables and responsiveness. For example, suppose that political systems are less responsive to "militant" protest leadership than to "nonmilitant" protest leadership. The intervening social support variables may partially explain this relationship. Militant leadership is likely to incur the hostility of many key sectors of the political community, and this hostility may be the cause of unresponsiveness. Conversely, nonmilitant leadership may be supported by these sectors, and this support may be the primary cause of responsiveness.

The important point about conceptualizing social support as an intervening variable is that it is not a "given" or a "constant" for protest groups but rather is a variable which is partially dependent on protesters themselves. Thus, protest groups may depend on social support for success, as suggested by many theorists, but appropriate behaviors by protest groups may enhance social support which, in turn, may enhance the responsiveness of political systems.

Given this model, three hypotheses will be formulated and tested. The first is general in nature and concerns the relative explanatory power of protester-controlled variables and social support variables. The second and third are more specific and explore the effects of particular social support and protester-controlled variables on policy responsiveness.

Hypothesis 1. Protester-controlled variables are less important than the environment of social support in explaining the policy responsiveness of local political systems to protest-group demands.

This hypothesis is drawn from literatures regarding elite responsiveness and protest-group power. Political elites appear to have role perceptions, attitudes, and values which make them relatively unresponsive to various protest-group demands and actions but relatively attentive to the attitudes of certain sectors of the community. Many officials appear to have adopted "representational response styles" making them immune to pressure from informal protest groups. Rather than responding to the pressures of "ad hoc issue groups," many city officials perceive their role as responding to "unattached individuals," to their own "self-defined image of community needs," or to "attentive publics."25 Verba and Nie note the great concurrence in the attitudes of public officials

25 M. Kent Jennings and Harmon Zeigler, "Response Styles and Politics: The Case of School Boards," Midwest Journal of Political Science, 15 (May 1971), 290-321; and Prewitt and Eulau, "Political Matrix," 430. 
and the attentive or active public, ${ }^{26}$ and thereby suggest that officials will not usually be responsive to protest groups unless active publics support the protest-group demands. Lowi argues that the symbiotic relationships between authorities and organized groups prevent the various actions of new groups from being purposively considered unless organized groups are supportive. ${ }^{27}$

The literature on protest groups also implies that responsiveness may be determined more by social support than by protest-group behaviors. Protesters are often viewed as having few power resources of their own and thus must get others in the community to apply their resources on behalf of the protest group. Lipsky has written that protesters "depended for success not upon direct utilization of power, but upon activating other groups to enter the political arena." 28 Murray Edelman succinctly summarizes this view by noting that what "lends power to a movement and provides a setting in which leadership can effectively operate [is] the distribution of social support."29

Hypothesis 2. The support or opposition of long-standing active groups in a community is a particularly important factor influencing the policy responsiveness of local political systems. However, the attitudes of agency officials, elected officials, the media, and the community as a whole are also significant factors affecting policy responsiveness.

The primary importance of active groups in the determination of policy responsiveness is suggested by group theory. Both pluralists and antipluralists have viewed policy in various issue areas as being determined by the "effective access" of various interest groups. ${ }^{30}$ In these views, policy is, in large part, the result of the interests and power of traditional pressure groups which dominate specific policy areas. Lipsky is the protest-group theorist who stresses the importance for protest groups of obtaining the support

26 Verba and Nie, Participation in America, 304-333.

27 Theodore J. Lowi, The End of Liberalism (New York: W. W. Norton \& Company, 1969), 87-89.

${ }^{28}$ Lipsky, Protest in City Politics, 1. 24.

29 Politics as Symbolic Action (Chicago: Markham Publishing Co., 1971),

30 For different views of the enormous influence which traditional interest groups have on public policy, contrast David Truman, The Governmental Process (2d ed.; New York: Alfred A. Knopf, 1971), 507, with Lowi, End of Liberalism, 55-97. 
of active groups, particularly those groups who are the reference publics of protest targets. For, according to Lipsky, "the essence of political protest consists of activating third parties to participate in the controversy in ways favorable to protest groups." ${ }^{11}$

Nevertheless, active groups may not be the only sector in the community whose attitudes are important determinants of policy responsiveness. ${ }^{32}$ The traditional group-theory notion that political authorities are neutral referees in the group struggle has been effectively challenged, and today there is much evidence that the attitudes of agency officials and elected officials greatly affect public policy. ${ }^{33}$ Thus it is hypothesized that the attitudes of these public officials will also affect policy responsiveness to protest-group demands.

Norton E. Long has suggested another sector of the community which plays an important role in the determination of public policy: the mass media.

A major protagonist of things in general in the territorial system is the newspaper. . . . In a sense, the newspaper is a prime mover in setting the territorial agenda. It has a great part in what most people will be talking about, what most people will think the facts are, and what most people will regard as the way problems should be dealt with. ${ }^{34}$

Thus the support or opposition of the media to protest-group de-

${ }^{31}$ Lipsky, Protest in City Politics, 172.

32 This criticism of Lipsky's over-emphasis on "third parties" has been made elsewhere. See Willis D. Hawley, review of Protest in City Politics by Michael Lipsky in the American Political Science Review, 64 (December 1970), 1,257. Peter Eisinger, in "Conditions of Protest Behavior," 15-16, has also noted that protest groups need not depend upon active groups.

33 The importance of the attitudes of public officials in urban policy-making is attested to by Gamson, Power and Discontent, 28-31; Heinz Eulau and Robert Eyestone, "Policy Maps of City Councils and Policy Outcomes," American Political Science Review, 62 (March 1968), 124-143; and Robert L. Crain, Elihu Katz, and Donald B. Rosenthal, The Politics of Community Conflict (Indianapolis: Bobbs-Merrill Company, 1969), 99-121. Yet, some researchers, such as Downs and Green, "Politics of Open Housing," continue to argue that the influence of elected officials is problematic. Lowi, End of Liberalism, 200206 , distinguishes between the power of agency officials and that of elected officials in affecting urban policy and argues that the former are very influential while the latter are quite powerless.

${ }^{34}$ Norton E. Long, "The Local Community as an Ecology of Games," American Journal of Sociology, 64 (November 1958), 259-260. 
mands is hypothesized to be another factor affecting policy responsiveness.

Finally the attitude of "the community as a whole," a concept similar to the notion of constituency as discussed by Miller and Stokes, may affect policy responsiveness. ${ }^{35}$ Even though it is difficult to speak of a political community or constituency as a monolithic united whole, the notion of "community attitude" or "constituency attitude" as a reservoir of general salient community opinion appears to have a psychological existence in the minds of authorities. The perception of dominant community attitudes is sometimes an important determinant of public policy. It is here hypothesized to affect policy responsiveness.

In summary, it is hypothesized that the attitudes of active groups are highly related to policy responsiveness. But it is also hypothesized that agency officials, elected officials, the media, and community as a whole play important roles in affecting the policy response of local polities to protest demands.

Hypothesis 3. Policy responsiveness should be reduced when protest groups adopt militant behaviors. Groups whose demands, actions, and leadership can be characterized as nonmilitant should be more successful than groups whose demands, actions, and leadership can be characterized as militant.

In the literature on protest-group politics, the notion of militancy has been much discussed, yet there has been little consensus as to the meaning of militancy or as to the effectiveness of militant citizen behaviors. Perhaps the most satisfying discussions of the concept have appeared in the Negro politics literature, particularly in the work of Wilson, Ladd, and Matthews and Prothro. ${ }^{36}$ This literature suggests that militancy is a multidimensional continuous variable indicated by protest-group characteristics concerning goals sought, means utilized, and the mannerisms of leadership. In particular, militancy is present when goals are adopted that are highly threatening to others in the community, when actions are undertaken that are combative, aggressive, and have an implied threat of

${ }^{35}$ Warren E. Miller and Donald E. Stokes, "Constituency Influence in Congress," American Political Science Review, 57 (March 1963), 45-56.

${ }^{36}$ James Q. Wilson, Negro Politics (Glencoe, Ill.: The Free Press, 1960), 214-254; Ladd, Negro Political Leadership, 145-232; and Donald R. Matthews and James W. Prothro, Negroes and the New Southern Politics (New York: Harcourt, Brace and World, 1966), 186-200. 
violence, and when leadership adopts rhetoric seeking to polarize the community by picturing the conflict as one involving the forces of good and evil. At the other end of the nonmilitancy/militancy continuum, nonmilitancy-variously labeled moderation, conservatism, and traditionalism in the Negro politics literature-is indicated by the adoption of goals which are not threatening to others in the community, by employing conventional political actions like litigation and negotiation, and by choosing leadership which speaks a language of amelioration and consensus-building.

In order to examine the effectiveness of militant behaviors, a number of dimensions of protest-group demands, leadership, and actions can be conceptualized which, on the basis of the previous literature and common sense, take values capable of being characterized as nonmilitant or militant. ${ }^{37}$ These variables and the values they take along a nonmilitant/militant continuum are summarized in Figure 2. ${ }^{38}$

The three demand variables in this analysis are the zero-sumness of demands, the status-welfare dimension of demands, and the status quo/change dimension of demands. The zero-sumness dimension is a theoretical concept concerned with the varying degrees in which protest-group demands imply either subjective or objective burdens for other groups in the community. At the operational level, some demands (for example, a demand for a stop light) normally approach the nonzero-sum end of the zero-sumness of demands continuum because they are not very threatening to others. $^{39}$ Other demands (for example, for two-way busing of school children) are perceived as falling much closer to the zerosum end of this continuum. Because the concept of militancy has been defined in terms of pursuing goals that are highly threatening

37 Organizational variables, which constitute the fourth dimension of the protester-controlled variables in Figure 1, are not considered in relation to this hypothesis because it is difficult to characterize organizational stability and size in terms of militant or nonmilitant behavior. However, the relationship of these variables to responsiveness is of sufficient theoretical importance to warrant considerable separate attention.

${ }^{38}$ For a somewhat similar chart, see Matthews and Prothro, Negroes and the New Southern Politics, 196.

${ }^{39}$ Michael Parenti, "Power and Pluralism," 512-513, describes just such a case. Political officials in Newark refused a request by inner city blacks for a stop light even though such a request seemed to imply few burdens for anyone. 
Figure 2

Charactertzing Demands, Leadership, and Actions on a Nonmilitant/Militant Continuom

\begin{tabular}{l|l|l|l}
\hline $\begin{array}{l}\text { Protester-control- } \\
\text { led Variables }\end{array}$ & $\begin{array}{l}\text { Nonmilitant } \\
\text { Behavior }\end{array}$ & $\begin{array}{l}\text { Intermediate } \\
\text { Behavior }\end{array}$ & $\begin{array}{l}\text { Militant } \\
\text { Behavior }\end{array}$ \\
\hline $\begin{array}{l}\text { Zero-sumness } \\
\text { Aspect of De- } \\
\text { mands }\end{array}$ & $\begin{array}{l}\text { Demands } \\
\text { Threaten No } \\
\text { Other Groups }\end{array}$ & $\begin{array}{l}\text { Demands Pose } \\
\text { Minor Threat } \\
\text { to Others }\end{array}$ & $\begin{array}{l}\text { Demands Pose } \\
\text { Major Threat } \\
\text { to Others }\end{array}$ \\
\hline $\begin{array}{l}\text { Status-welfare } \\
\text { Aspects of } \\
\text { Demands }\end{array}$ & $\begin{array}{l}\text { Demands for } \\
\text { Material Benefits }\end{array}$ & $\begin{array}{l}\text { Seek Rights } \\
\text { Linked to Mat- } \\
\text { erial Benefits }\end{array}$ & $\begin{array}{l}\text { Demands for } \\
\text { Rights }\end{array}$ \\
\hline $\begin{array}{l}\text { Status quo/ } \\
\text { Change Aspect } \\
\text { of Demands }\end{array}$ & $\begin{array}{l}\text { Demands to } \\
\text { Uphold the } \\
\text { Status Quo }\end{array}$ & $\begin{array}{l}\text { Demands for } \\
\text { Policy Changes }\end{array}$ & $\begin{array}{l}\text { Demands for } \\
\text { Regime Changes }\end{array}$ \\
$\begin{array}{l}\text { Ideology of } \\
\text { Leadership }\end{array}$ & $\begin{array}{l}\text { Projects a Con- } \\
\text { servative Style }\end{array}$ & $\begin{array}{l}\text { Projects a Mod- } \\
\text { erate Style }\end{array}$ & $\begin{array}{l}\text { Projects a } \\
\text { Radical Style }\end{array}$ \\
\hline $\begin{array}{l}\text { Externalness of } \\
\text { Leadership }\end{array}$ & $\begin{array}{l}\text { All Leaders Are } \\
\text { Indigenous }\end{array}$ & $\begin{array}{l}\text { Outsiders } \\
\text { Participate } \\
\text { in Protest }\end{array}$ & $\begin{array}{l}\text { Outsiders Dom- } \\
\text { inate Protest }\end{array}$ \\
\hline $\begin{array}{l}\text { Unconventional- } \\
\text { ity of Protest } \\
\text { Actions }\end{array}$ & $\begin{array}{l}\text { Negotiate with } \\
\text { Public Officials }\end{array}$ & $\begin{array}{l}\text { Use Nonviolent } \\
\text { Direct Action }\end{array}$ & Use Violence \\
\hline
\end{tabular}

to others, the more zero-sum are protest-group demands, the more militant is the protest group.

The status-welfare dimension of demands is a theoretical concept concerned with the varying degrees to which protest groups seek equal rights (status) and/or specific and concrete services (welfare). According to James Q. Wilson, demands which are predominantly status-oriented can be characterized as militant, and demands which are predominantly welfare-oriented can be characterized as nonmilitant.

The moderate, in contrast to the militant, tends to seek welfare rather than status ends. . . . In those areas of civic life where moderates contribute their energies, they are more likely to choose the welfare aspects of issues, where such a choice is necessary, and they are the leaders responsible for those statements endorsing better schools, more public housing, a branch hospital, more Negro representation, and more private housing in preference to the more remote status ends. ${ }^{40}$

${ }^{40}$ Wilson, Negro Politics, 235. 
The status quo/change dimension of demands is concerned with the degree to which demands are change-oriented. Lipsky, who calls goal defensiveness and goal assertiveness the polar variations on this continuum, writes that "goal defensiveness or assertiveness refers to whether protest activity is directed toward maintaining or securing some previously held value or whether it is directed toward promoting some new value."41 Following conventional usage, demands for change can be characterized as radical or militant behavior, and demands to uphold the status quo can be described as nonmilitant behavior.

Two dimensions of leadership have values that can be characterized on a militancy continuum. The first is its projected ideology. Protest leaders adopt various "styles," vocabularies, rhetoric, and the like which result in their being perceived as conservative, moderate, liberal, or radical, the conservative styles implying nonmilitancy whereas the radical styles indicate militancy. ${ }^{42}$ The second dimension of leadership is the extent to which it is drawn from outside of the community (its "externalness"). Because the term "outsider" has so frequently been linked with the term "agitator" in the minds of community targets, the use of external leaders is here characterized as militant behavior.

A dimension of protest-group actions may also take values that can be characterized on a militancy continuum. This dimension measures the extent to which protest-group actions are predominantly conventional (for example, negotiating with public officials, attending public hearings, circulating petitions, and so on) or unconventional (ranging from holding rallies and demonstrations through using violence). Again, following Wilson, unconventional actions are characterized as militant behaviors. ${ }^{43}$

The hypothesis that nonmilitant demands, leadership, and actions enhance policy responsiveness is based on the previous hypothesis that policy responsiveness should be greatly affected by the distribution of social support. The earlier literature suggests that militant behaviors are not likely to be supported by many actors in the community. Indeed, Eisinger has recently written that "most

${ }^{41}$ Lipsky, Protest in City Politics, 196-197.

42 For a discussion of leadership ideology and style, see Ladd, Negro Political Leadership, 145-232, and Wilson, Negro Politics, 214-254.

43 Wilson, Negro Politics, 221-226 and 238-246. 
surveys which have sought to tap attitudes toward [unconventional] protest have revealed predominantly hostile sentiments." 44 These considerations suggest the hypothesis that a developmental sequence occurs between protester-controlled variables and policy responsiveness whereby nonmilitant behaviors enhance social support which, in turn, enhances the policy responsiveness of political systems.

\section{Data Sources}

In order to test and elaborate on the above hypotheses, two samples of data regarding protest activity in American communities have been collected: (1) protest incidents based on a content analysis of case studies; and (2) protest incidents based on information attained from questionnaires. The decision to collect and analyze two different samples stemmed from the belief that each of the two data collection procedures had certain deficiencies which might result in biases.

\section{The Case Studies Sample}

Local protest incidents were selected for inclusion in this sample on the basis of the availability of written reports on the incident. If enough written material was available so that most of the theoretical concepts could be measured, then the incident was included in the sample. ${ }^{45}$ Over 125 incidents were coded, but a number were omitted from the final analysis because data were insufficient. The final size for the case study sample was 93 .

Data on these 93 incidents were collected from the following sources: published scholarly and journalistic case studies, unpublished dissertations, the New York Times, and local newspapers. Generally, the procedure was to examine the case studies first and attain information on as many variables as possible. Then the

44 "Racial Differences in Protest Participation," 593.

45 For other illustrations of this data collection technique in community research, see John Walton, "A Systematic Survey of Community Power Research," in The Structure of Community Power, ed. Michael Aiken and Paul Mott (New York: Random House, 1970), 443-464; and Claire W. Gilbert, Community Power Structure: Propositional Inventory, Tests, and Theory (Gainesville: University of Florida Press, 1972), 1-6. 
New York Times was examined for articles on the incident to obtain information on those variables for which data were missing in the case studies and to check the accuracy of the initial case study. Finally, if data were still missing on key variables, the local newspaper accounts were read. When the various data sources were not in agreement about certain factual matters, the New York Times was considered to be the most reliable data source, and the variables were coded on the basis of its accounts.

From the descriptive and qualitative accounts of the protest incidents in these data sources, scaled measures of the theoretical concepts were obtained. This transformation of essentially qualitative data into quantitative data was accomplished by conceptualizing each of the theoretical variables as having an underlying unidemensional continuum which could be approximated by a five-point ordinal scale. To facilitate scaling, coders were instructed to consider all of the available qualitative data for each incident, to derive impressions of the relative value of each variable for each incident, and to measure their impressions by using a five-point ordinal scale. In addition, specific guidelines and examples were provided to assist coder judgment. For example, the scale used in measuring policy responsiveness and the guidelines for scaling this variable were as follows:

(1) Repressive policy responses. Responding by taking no actions favorable to protest groups and, instead, taking some actions which are unfavorable or repressive to them.

(2) No action. The failure to take any action of either a repressive or responsive nature.

(3) Minimal policy responses. Responding by taking such actions as (a) establishing a program or law which is concerned with alleviating the protest grievances but which does not satisfy the protest group; (b) making token gestures; or (c) passing symbolic legislation.

(4) Compromise policy responses. Responding by giving protest groups some, but not all, of what they demand.

(5) Responsive policy actions. Responding by enacting policies congruent with the demands of protest groups.

Because of the subjectivity involved in attaining quantitative measures from the qualitative accounts in the case studies, two researchers made independent measurements of the key theoretical variables. Analysis suggested that the measures were quite reliable (the correlation coefficients between the measures of the two 
observers were .80 or better for all but two variables $)^{46}$ and that the measurement errors were of a random rather than systematic variety.

\section{The Questionnaire Sample}

In order to complement the case studies sample, a second sample of local protest incidents was collected by mailing questionnaires to 300 officials in 46 cities. These questionnaires were sent to officials in agencies which are among the chief providers of controversial municipal services: (1) occupants of city hall (managers and mayors); (2) school administrators; (3) directors of welfare departments; (4) directors of health departments; (5) directors of pollution and environmental control agencies; (6) directors of housing agencies; and (7) local model cities and urban renewal administrators. These officials returned 201 questionnaires, 119 of which were deemed usable. ${ }^{47}$

The respondents to the questionnaire acted as informants providing data-elicited through a combination of forced-response and open-ended questions-regarding the most recent protest incident targeted at their agency. For the variables measured by forcedresponse questions, the perceptions of the informants were used as indicators of the theoretical concepts. For those variables measured by open-ended questions, the measurement procedures were similar to those used in the case studies sample. Because these measurements again involved coder subjectivity, two researchers independently coded these variables. Again, analysis suggested that the measures were quite reliable and free of bias by the coders. $^{48}$

It must also be noted that some of the measures in the question-

46 The two variables having low reliability were the degree to which protestgroup demands are change-oriented $(r=.61)$, and the degree to which protestgroup demands were threatening to others $(r=.78)$.

47 The main sources of unusable questionnaires were (1) agencies indicating that they had not been the target of any protest-group demands and therefore failing to provide any data usable for testing the hypotheses developed in this study $(N=54)$; and (2) agencies which returned questionnaires having missing data on crucial variables. In this respect, a number of informants could provide no data on responsiveness because the protest incident was still in progress $(N=18)$.

48 The only variable having a reliability coefficient of less than .80 in this sample was the zero-sumness dimension of demands $(r=.72)$. 
naire sample are less precise than those in the case studies sample. Although all variables were measured on five-point scales in the case studies sample, some independent variables were measured dichotomously or trichotomously in the questionnaire sample. $.^{49} \mathrm{Be}-$ cause of these differences in the scaling of variables in the two samples, standardized regression coefficients and correlation coefficients are reported so as to maximize comparability..$^{50}$

The data used in this study clearly have certain deficiencies. First, neither of the two samples is random. As suggested in Table 1 , the following types of protest incidents are over-represented in the case studies sample: those of civil rights groups; those occurring in the South and Northeast; those occurring in the 1960s; and protest where direct action tactics and/or violence was used. In the questionnaire sample, however, the following types of protest incidents were overrepresented: that of neighborhood groups; that occurring in the Midwest; protest occurring in the early 1970s; and that involving conventional strategies. In addition to the nonrandom aspects of our samples revealed in Table 1, it should also be noted that most of the incidents in the case studies sample were very conspicuous, often drawing national attention, while those in the questionnaire sample were less widely known and reported. In short, because neither sample is random, caution must be exercised in generalizing on the basis of the data. Nevertheless, the wide variety of protest incidents examined in the two samples cumulatively provides a much better basis for generalizing than do the numerous single-incident case studies which dominate the literature.

In addition to sampling error, the data reported here have certain measurement errors. Beyond that due to coder subjectivity, the data may have some measurement error resulting from the bias of

49 Because of the need to provide informants with a short, simple questionnaire, less information was collected regarding protest incidents in the questionnaire sample than was collected for incidents in the case studies sample. This difference resulted in the decision to code some variables less precisely in the questionnaire sample.

50 Because our measures do not have the precision of interval level measures required by regression procedures, the decision to report standardized regression coefficients may appear inappropriate. However, see Ted Robert Gurr, Politimetrics: An Introduction to Quantitative Macropolitics (Englewood Cliffs, N. J.: Prentice-Hall, Inc., 1972), 62-63, for a discussion of the advantage of using regression techniques on noninterval level data. 


\section{TABLE 1}

\section{Case Studies Sample and Questionname Sample} Described and Compared

\begin{tabular}{|c|c|c|c|c|}
\hline & \multicolumn{2}{|c|}{ Case Studies Sample } & \multicolumn{2}{|c|}{ Questionnaire Sample } \\
\hline & Frequency & Percentage & Frequency & Percentage \\
\hline \multicolumn{5}{|l|}{ Size of City Where } \\
\hline \multicolumn{5}{|l|}{ Incident Occurred ${ }^{\mathrm{a}}$} \\
\hline Below 50,000 & 16 & 17 & 7 & 7 \\
\hline $50,000-200,000$ & 21 & 23 & 19 & 18 \\
\hline $200,000-500,000$ & 16 & 17 & 28 & 26 \\
\hline $500,000-1,000,000$ & 13 & 14 & 39 & 37 \\
\hline Over $1,000,000$ & 27 & 29 & 13 & 12 \\
\hline \multicolumn{5}{|l|}{ Region ${ }^{2}$} \\
\hline Northeast & 40 & 43 & 23 & 22 \\
\hline Midwest & 13 & 14 & 53 & 50 \\
\hline West & 7 & 7 & 22 & 21 \\
\hline South & 33 & 36 & 8 & 7 \\
\hline \multicolumn{5}{|l|}{ Year When Incident Began } \\
\hline Prior to 1960 & 4 & 4 & 0 & 0 \\
\hline $1960-64$ & 52 & 56 & 0 & 0 \\
\hline $1965-69$ & 36 & 39 & 2 & 2 \\
\hline 1970 and After & 1 & 1 & 117 & 98 \\
\hline \multicolumn{5}{|l|}{ Nature of Protest Group ${ }^{b}$} \\
\hline Civil Rights Group & 60 & 65 & 23 & 19 \\
\hline Neighborhood Group & 19 & 20 & 58 & 49 \\
\hline Students & 13 & 14 & 28 & 24 \\
\hline Parents of Students & 19 & 20 & 27 & 23 \\
\hline Welfare Recipients & 7 & 7 & 29 & 24 \\
\hline Environmentalists & 4 & 4 & 11 & 9 \\
\hline Others & 13 & 14 & 25 & 21 \\
\hline \multicolumn{5}{|l|}{$\begin{array}{l}\text { Predominant Actions of } \\
\text { Protest Group }\end{array}$} \\
\hline Conventional & 21 & 23 & 61 & 53 \\
\hline Unconventional & 72 & 77 & 58 & 48 \\
\hline \multicolumn{5}{|l|}{$\begin{array}{l}\text { Policy Response of Local } \\
\text { Political System }\end{array}$} \\
\hline Repression & 6 & 6 & 2 & 2 \\
\hline No Response & 26 & 28 & 36 & 30 \\
\hline Minimal Response & 26 & 28 & 20 & 17 \\
\hline Compromise Response & 19 & 20 & 39 & 33 \\
\hline Adopt Policy Congruent & & & & \\
\hline with Protest Demands & 16 & 17 & 22 & 18 \\
\hline
\end{tabular}

The questionnaire sample totals 106 rather than 119 because the cities of 13 returned questionnaires could not be identified.

because some protest groups could be characterized in several ways, the totals exceed 100 percent. 
the original data sources. On the one hand, the scholars and journalists who provided data for the case studies sample appeared frequently to sympathize with the protest groups; these sympathies may have resulted in their underestimating policy responsiveness. On the other hand, the city officials who provided data for the questionnaire sample, because they tend to view protest incidents from another perspective, are likely to have overestimated their responsiveness.

In summary, the data used in this study are subject to some unavoidable sampling and measurement errors. An effort has been made to minimize these biases and deficiencies by collecting two data sets whose limitations partially offset each other. Nevertheless, the results of the data analysis must be considered exploratory.

\section{Explanations of Responsiveness: Results of Some Tests}

We come now to testing and discussing the three hypotheses developed earlier.

Hypothesis 1. The hypothesis that protester-controlled variables are less important than the environment of social support in explaining policy responsiveness is crucial to understanding the power of protest groups. To the extent that policy responses are affected by factors directly within the control of protest groups, it can be contended that protest groups have the ability to influence responsiveness through the adoption of effective behaviors. The data in Tables 2 and 3 examine the combined and independent effects of protester-controlled variables and social support variables on policy responsiveness.

Because the data in Table 2 indicate that less than 20 percent of the variance in policy responsiveness is accounted for by the eight protester-controlled variables listed in Figure 1 and because about 30 percent of the variance in policy responsiveness is accounted for by the five social support variables also listed in Figure 1 , the original hypothesis is supported by the data in both samples. Social support variables do appear to account for more of the variation in policy responsiveness than do factors within the direct control of protest groups.

Another indication of the importance of protester-controlled variables relative to social support variables in affecting policy responsiveness can be gleaned from Table 3, which reports the zero-order correlations $\left(r_{o}\right)$, the partial correlations $\left(r_{p}\right)$, and the 
TABLE 2

Determinants of Policy Responsiveness By Variable Category

\begin{tabular}{|c|c|c|c|c|c|c|c|c|}
\hline & \multicolumn{4}{|c|}{ Case Studies Sample } & \multicolumn{4}{|c|}{ Questionnaire Sample } \\
\hline & \multicolumn{2}{|c|}{$\begin{array}{c}\text { Multiple } \\
\text { Coefficients }\end{array}$} & \multicolumn{2}{|c|}{$\begin{array}{l}\text { Multiple- } \\
\text { partial } \\
\text { Coefficients }\end{array}$} & \multicolumn{2}{|c|}{$\begin{array}{l}\text { Multiple- } \\
\text { Coefficients }\end{array}$} & \multicolumn{2}{|c|}{$\begin{array}{c}\text { Multiple } \\
\text { partial } \\
\text { Coefficient }\end{array}$} \\
\hline & $\mathbf{R}$ & $\mathbf{R}^{2}$ & $\mathbf{R}$ & $\mathbf{R}^{2}$ & $\mathbf{R}$ & $\mathbf{R}^{2}$ & $\mathbf{R}$ & $\mathbf{R}^{2}$ \\
\hline $\begin{array}{c}\text { Protester- } \\
\text { controlled } \\
\text { Variables }\end{array}$ & & & & & & & & 10 \\
\hline Social & .42 & .18 & & .09 & & & & \\
\hline $\begin{array}{l}\text { Support } \\
\text { Variables }\end{array}$ & .58 & .34 & .52 & .27 & .53 & .28 & .46 & .21 \\
\hline $\begin{array}{l}\text { Protester- } \\
\text { controlled } \\
\text { and Social } \\
\text { Support Variables }\end{array}$ & .64 & .40 & & & .59 & .35 & & \\
\hline
\end{tabular}

partial standardized regression coefficients $(\beta$ 's) relating each independent variable with policy responsiveness. ${ }^{51}$ Of the 14 betaweights ( $\beta$ 's) relating protester-controlled variables to policy responsiveness, only six ( 43 percent) are significant at the .05 level; but of the ten beta-weights relating social support variables to policy responsiveness, eight ( 80 percent) are significant at the .05 level. In short, the data in Table 3 support the hypothesis that the various dimensions of social support are more strongly related to policy responsiveness than are the various protester-controlled variables. ${ }^{2}$

The weak relationships between protester-controlled variables

51 The beta-weights and partial correlation coefficients in Table 3 indicate the relationship between the various independent variables and responsiveness, controlling for all other variables within the construct. Thus, in examining a particular protester-controlled variable, other protester-controlled variables are controlled but social support is not controlled. Likewise, in examining a particular support sector, other support variables are controlled whereas protestercontrolled variables are not controlled.

52 Nevertheless, protest groups are not totally dependent on social support. The stochastic nature of the relationship between obtaining support and obtaining favorable responses is obvious. Indeed, when examining the relationships between social support and policy responsiveness in Tables 2 and 3, the surprising result is that the relationships are not stronger than is shown. Protest groups having the support of key sectors of the community sometimes fail to gain policies responsive to their demands, and groups lacking support seem to have had some successes. 
TABLE 3

Determinants of Policy Responsiveness By Spectfic Variables

\begin{tabular}{|c|c|c|c|c|c|c|}
\hline & \multicolumn{3}{|c|}{ Case Studies Sample } & \multicolumn{3}{|c|}{ Questionnaire Sample } \\
\hline & $\mathbf{r}_{0}$ & $\beta$ & $\mathbf{r}_{\mathbf{p}}$ & $\mathbf{r}_{0}$ & $\beta$ & $\mathbf{r}_{\mathbf{p}}$ \\
\hline \multicolumn{7}{|l|}{ Protester-controlled Variables } \\
\hline \multicolumn{7}{|l|}{ Demand Dimensions } \\
\hline Status-Welfare & .33 & $.29 *$ & .22 & .20 & .05 & .06 \\
\hline Zero-Sumness & -.30 & $-.21^{*}$ & -.16 & -.36 & $-.31 *$ & -.31 \\
\hline Status Quo/Change & -.01 & $.20^{*}$ & .18 & -.09 & .10 & .03 \\
\hline \multicolumn{7}{|l|}{ Organizational Dimensions } \\
\hline Number of Active Participants & .05 & .11 & .11 & .00 & .09 & .05 \\
\hline Organizational Stability & -.06 & $-.14^{*}$ & -.14 & .01 & .01 & -.03 \\
\hline \multicolumn{7}{|l|}{ Leadership Dimensions } \\
\hline Externalness of Leadership ${ }^{\mathbf{b}}$ & -.05 & .00 & .00 & & & \\
\hline Radicalness of Leadership ${ }^{b}$ & & & & -.22 & $-.14^{*}$ & -.14 \\
\hline \multicolumn{7}{|l|}{ Actions } \\
\hline \multicolumn{7}{|l|}{ Unconventionality of } \\
\hline Protest-Group Actions & -.02 & -.04 & -.03 & -.26 & -.17 & -.12 \\
\hline \multicolumn{7}{|l|}{ Environment of Social Support } \\
\hline Agency Officials Support & .20 & $.18^{*}$ & .21 & .46 & $.35^{\circ}$ & .29 \\
\hline Elected Officials Support & .32 & $.20^{\circ}$ & .20 & .37 & $.23^{*}$ & .21 \\
\hline Media Support & .15 & $-.24 *$ & -.23 & .16 & -.12 & -.08 \\
\hline Active Group Support & .45 & $.34^{*}$ & .32 & .32 & $.21 *$ & .16 \\
\hline Community Support & .44 & $.27^{\circ}$ & .27 & .28 & -.05 & .00 \\
\hline
\end{tabular}

Throughout this paper, an asterisk indicates statistical significance at the .05 level. Because no claim is being made that the samples are random, the use of significance tests is not really appropriate. Significance is indicated only to help the reader determine the importance of the relationships.

"The variable "externalness of leadership" was coded in the case studies only; the variable "radicalness of leadership" was coded in the questionnaire sample only.

and policy responsiveness suggest the limited nature of opportunities available for protest groups to manipulate the determinants of policy responsiveness to their own advantage. However, the tentative nature of this assertion must be stressed. First, the relatively weak relationships between protester-controlled variables may be, in part, a function of measurement error. ${ }^{53}$ Secondly, it must be remembered that not all, and perhaps very few, protester-controlled

53 Random measurement error will result in underestimates of the "true" 
variables have been considered and measured. As other variables controllable by protest groups are measured and brought into the model, the ability of protester-controlled variables to explain policy responsiveness might be appreciably enhanced. Thirdly, the assertion that protester-controlled variables are weakly related to policy responsiveness may be true as a broad generalization, but certain protester-controlled variables under specific conditions may be strongly related to responsiveness. ${ }^{54}$ Fourth, some protester-controlled variables in Table 3 are nevertheless generally related to policy responsiveness in indicative manners. Thus, although the relationships between protester-controlled variables and policy responsiveness are quite weak, the conclusion should not be drawn that appropriate behaviors by protest groups cannot enhance policy responsiveness.

Hypothesis 2. The second hypothesis examines how policy responsiveness is affected by the attitudes of five segments of the local polity: active groups, the community as a whole, agency officials, elected officials, and the media. The notion that active groups are particularly important in affecting the policy responsiveness of communities to protest-group demands is supported by the data in Table 3. The direct effect of active group attitudes on responsiveness is suggested by the fact that $\beta=.34$ in the case studies sample and $\beta=.21$ in the questionnaire sample. In both samples the relationship between active group support and policy responsiveness is significant and strong relative to the relationships between other support sectors and policy responsiveness. This relationship suggests that, when confronted with protest groups, community officials often look to active groups for cues and "respond in some way ... [which] satisfies their reference publics." ${ }^{55}$

The role of active groups in affecting policy responsiveness to protest-group demands can be compared to the role of the inactive public ("the community as a whole"). Consistent with the implica-

strength of the relationships among our variables. See John Johnston, Econometric Methods (New York: McGraw-Hill Book Co., 1963), 148-176.

54 In other words, there may be interaction effects whereby the weak general relationships reported here become strongly positive under some conditions and strongly negative under other conditions. See Hayward Alker, Jr., Mathematics and Politics (New York: Macmillan Company, 1965), 106-111, for a discussion of interaction effects.

${ }^{55}$ Lipsky, Protest in City Politics, 175. 
tions of Lipsky and group theorists generally, the data indicate that policy responsiveness is apparently less influenced by the inactive public than by the active public. Although the support of the community as a whole is positively and significantly related to responsiveness in the case studies sample, no significant relationship exists in the questionnaire sample. This difference suggests that the community as a whole does not play the consistently important role in affecting policy responses to protest-group demands that is played by active groups; instead, inactive publics may be important determinants of responsiveness only under specifiable conditions (for example, when protest is conspicuous or unconventional) that are over-represented in the case studies sample. ${ }^{56}$

The attitudes of political authorities, as well as the attitudes of active and inactive publics, may also affect policy responsiveness to protest-group demands. Yet, this possibility seems to be discounted by the leading protest-group theorist, Michael Lipsky. Lipsky writes that "in contrast to the simplistic pressure group model which would posit a direct relationship between pressure group and pressured, the following discussion is guided by the assumption (derived from observation) that protest is a highly indirect process." ${ }^{7}$ As an indirect process, the "communications media and reference publics"-not the targets-play crucial roles in determining the response of local political systems. Lipsky, then, suggests that the attitudes of political authorities (agency officials and elected officials) are not highly influential. However, the data in Table 3 indicate that the attitudes of both agency officials and elected officials are important independent variables affecting policy responsiveness. In both samples, the attitudes of elected and agency officials are significantly related to policy responsiveness. The attitudes of these authorities appear to be particularly important for the types of protest (for example, inconspicuous and conventional protest) overrepresented in the questionnaire sample.

56 Specification of the conditions under which the attitudes of various sectors of the community are of minimal and maximal importance in affecting responsiveness is an interesting theoretical problem having important prescriptive implications. This subject is considered in the larger study from which this paper is derived. See Paul Schumaker, "The Power of Protest Groups: System Responsiveness to Citizen Demands" (unpublished Ph.D. dissertation, University of Wisconsin-Madison, 1973), 220-263.

${ }^{57}$ Lipsky, Protest in City Politics, 4. 
A final sector of the community whose attitudes may affect policy responsiveness is the media. In addition to transmitting information about protest groups and their demands, the media may also, through biased coverage and editorial positions, play an advocating role. ${ }^{58}$ One would expect that media support would enhance policy responsiveness to protest-group demands, but the data in Table 3 are somewhat inconclusive in this respect. If one looks at the partial correlation and regression coefficients concerned with the independent effect of media support on policy responsiveness, the relationship appears to be negative-significantly so in the case studies sample. This finding is an anomaly which may or may not be explained by the notion that local newspapers often support unpopular causes. However, the zero-order correlation coefficients show positive relationships, indicating a more intuitively satisfying conclusion that responsiveness is enhanced by media support.

The explanation for the divergence between the positive zeroorder relationship and the negative partial relationship in this case is that media support influences policy responsiveness indirectly by affecting the attitudes of other sectors of the community. ${ }^{59}$ Protest groups might profitably seek media support because it may win support from other segments of the community and thus result in enhanced policy responsiveness.

In summary, the second hypothesis is correct in assuming that the attitudes of active groups are particularly important determinants of policy responsiveness to protest-group demands. Nevertheless, the emphasis which Lipsky gives to active groups appears to be overstated. By viewing agency officials, elected officials, the media, and the community as a whole as additional sectors whose support or opposition influence policy responsiveness to protestgroup demands, a richer more accurate picture of the environment of social support is attained. It appears that protest groups can profitably court favor here as well.

Hypothesis 3. The final hypothesis is that policy responsiveness

58 It is the media's role in transmitting information, rather than their role as advocates, which Lipsky, Protest in City Politics, 169-172, apparently believes is critical to protest-group success.

59 For a discussion of direct and indirect relationships among variables and appropriate techniques to discern these relationships, see the discussions by Sewell Wright, Otis Dudley Duncan, and Hubert Blalock, Jr., in Causal Models in the Social Sciences, ed. Hubert Blalock, Jr. (Chicago: Aldine Publishing Co., 1971), 101-151. 
is reduced when protest groups adopt militant behaviors. It can be tested by examining the impact of various protest-group demands, actions, and leadership characteristics on policy responsiveness.

Regarding demands, our hypothesis suggests that policy responsiveness should be enhanced as demands become nonzero-sum, welfare, and/or status quo in orientation. The data in Table 3 partially support this proposition. First, the zero-sum dimension of demands is negatively related to policy responsiveness. As expected, policy responsiveness is reduced as protest-group demands become increasingly burdensome for other people in the community. Secondly, the status-welfare dimension of demands is positively related to policy responsiveness. Again, the hypothesis correctly suggests that policy responsiveness is increased as demands become nonmilitant-as they express concern for material benefits rather than for "rights." Nevertheless, the status-welfare dimension is less strongly related to responsiveness in the questionnaire sample than in the case studies sample. It is possible to speculate that this difference may be due to the time periods covered in the two samples. Cultural changes in the past decade have made status demands less difficult to respond to than previously. ${ }^{60}$ It may also be possible that city officials are no longer as willing to satisfy groups whose primary demands simply require the allocation of material resources. In any event, the data suggest that there has been, and may still be, a systematic bias against status demands.

The status quo/change dimension of demands, however, is not related to policy responsiveness as our hypothesis would suggest. Insignificantly weak zero-order relationships in the hypothesized direction change valence (and in the case studies sample become significant) when other protester-controlled variables are controlled. Perhaps it is not change per se which is resisted by local officials; rather it is the other behaviors and characteristics of protest groups making demands for change which cause resistance. ${ }^{61}$

${ }^{60}$ Those who are making status demands may have changed in the past decade. In the sixties, status demands were primarily raised by blacks; in the seventies, status demands are frequently made by various white protest groups who feel that their rights are being deprived.

${ }^{61}$ Indeed, because protest groups often protest against agency-induced changes, protest targets frequently resist protest groups who seek to maintain the status quo. For a discussion of these notions, see J. Clarence Davies III, Neighborhood Groups and Urban Renewal (New York: Columbia University Press, 1966). 
Regarding leadership, our hypothesis suggests that policy responsiveness should be enhanced when group leadership is indigenous to the local community and when leadership projects nonmilitant styles. Again, the hypothesis is partially validated by the data in Table 3. On the one hand, the hypothesized negative relationship between using external leaders and policy responsiveness is not validated. In the case studies, where variation in this leadership variable could be observed, there was no relationship between use of internal or external leadership and the policy responsiveness of community officials. It may be that external leaders possess certain skills and resources (for example, organizational abilities, rhetorical gifts, charisma, and the like) which make them useful under certain conditions and which balance whatever liabilities they bring to the protest movement. The liabilities may include the belief by the authorities that demands articulated by outsiders do not reflect indigenous grievances or sentiment. On the other hand, the hypothesized negative relationship between having leadership which projects a militant style and attaining responsive policies is apparently supported by the data. In the questionnaire sample, the perception of militant leadership styles was negatively related to policy responsiveness.

Regarding protest-group actions, our hypothesis suggests that policy responsiveness should be reduced as protest groups use increasingly militant actions. This hypothesis receives very weak support from the data presented in Table 3. Although the zeroorder relationship between unconventionality of actions and policy responsiveness is significant and in the hypothesized direction in the questionnaire sample $(\mathrm{r}=-.26)$, the relationship is weakened and becomes insignificant when controls are applied for the other protester-controlled variables. ${ }^{62}$ Also in the case studies sample, the weak negative relationship is insignificant, a finding which suggests that if a relationship between the unconventionality of actions and policy responsiveness exists, it is not well captured by the simple linear, additive, and recursive model examined in this

62 This negative relationship between unconventionality of actions and policy responsiveness is partially spurious owing to the demand variables. Groups making militant demands tend to adopt unconventional actions and attain relatively few policy successes. Groups making nonmilitant demands tend to use conventional actions and attain relatively frequent policy successes. 
paper. $^{63}$ For present purposes, then, it is concluded that militant protest actions have little direct and noninteractive effect on the responsiveness of local officials to protest-group demands.

In summary, the hypothesis that policy responsiveness is enhanced by moderate protest behaviors receives some support from the data. Some protest characteristics which can be described as nonmilitant do seem to enhance responsiveness. No protest characteristics which can be described as militant seem to enhance responsiveness. However, because the relationships are weak, broad generalizations about the effectiveness of nonmilitant behaviors must be tentative. It makes sense to suppose that these relationships are weak because nonmilitant behaviors are effective under some conditions while militant behaviors are effective under other conditions. Specification of these conditions thus becomes a key task of future research.

In order to understand further the impact of moderate and militant behaviors on responsiveness, it is instructive to examine the impact of protest demands, leadership, and actions of social support. Our model suggests a developmental sequence in which protestercontrolled variables affect social support which, in turn, affects responsiveness. If militant protest-group behaviors diminish responsiveness, it may be because such behaviors diminish the support of those sectors of the community whose attitudes are important determinants of policy responsiveness. The effects of zerosum demands, external leadership, radical leadership, and unconventional actions on the support of agency officials, elected officials, the media, active groups, and the community as a whole are indicated in Table 4.

The data generally support the notion that militant behaviors decrease social support. As protest groups make demands that are increasingly burdensome to others in the community, the support of the various sectors of the community appears to diminish significantly. The relationships between having external leaders and attaining support are negative in all cases, although significantly negative only for elected officials and the community as a whole.

${ }^{63}$ For a discussion of curvilinear, interactive, and nonrecursive models of this relationship, see Schumaker, "Protest Actions and Policy Responsiveness: Some Alternative Models" (paper presented at the 70th annual meeting of the American Political Science Association, Chicago, Ill., August 29-September 2, 1974). 


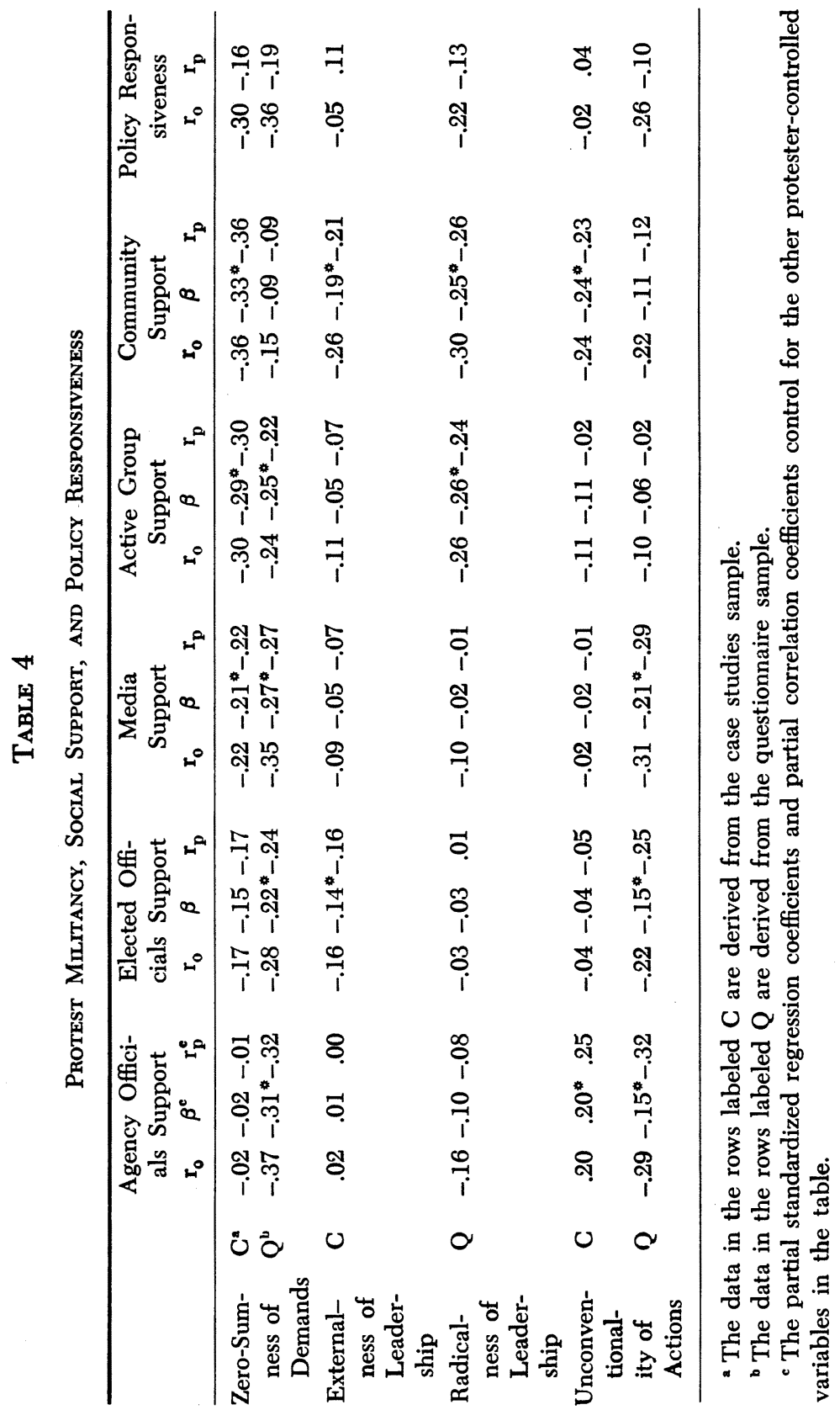


The relationships between having leaders who are labeled as radical and attaining support are also negative in all cases, although significantly so only for active groups and the community as a whole. Finally, the use of unconventional action also appears to be generally related to increased hostility toward the protest groups and their demands by various sectors of the community. In summary, the data in Table 4 generally confirm the notions that nonmilitant behaviors increase social support which, in turn, increases the policy responsiveness of local systems, and that militant behaviors decrease social support which, in turn, decreases policy responsiveness.

It might still be argued, however, that militant actions can be functional for protest groups because they may serve to coerce or force political authorities to adopt responsive policies. Because coercion seeks to change behavior directly rather than indirectly through a change in attitudes, its impact should be measured by the direct effects which militant behaviors have on responsiveness. To determine this direct effect, the last column of Table 4 reexamines the impact which protest demands, leadership, and actions have on policy responsiveness when social support and other protest-group characteristics are controlled. As can be seen by comparing the zero-order $\left(r_{0}\right)$ and partial $\left(r_{p}\right)$ correlations, the negative effects of militancy on responsiveness are reduced by controlling for social support. However, the positive effects of militancy remain obscure. Militancy, then, has little direct coercive effect in enhancing policy responsiveness in American communities.

In summary, because militant behaviors generally have little direct coercive effect and have the indirect effect of decreasing social support, protest-group militancy appears to be inversely related to policy responsiveness.

\section{Summary AND Conclusions}

This paper has attempted to develop a partial explanation of the varying policy responses of local political systems to the demands of groups of citizens who coalesce on an informal issue-specific basis. In order to have prescriptive value, the paper has focused on determinants of responsiveness that can be directly or indirectly manipulated by protest groups themselves. The conclusion that attaining favorable policy responses is enhanced by adopting nonmilitant behaviors is suggestive in this respect. 
However, this analysis may not warrant the conclusion that social scientists who wish to aid protest groups should prescribe nonmilitant behaviors. First, only the impact on policy responsiveness of adopting moderate and militant behaviors has been examined. Nothing has been said about what types of behaviors result in impact responsiveness. Nor has anything been said about what types of behaviors are most useful for building those power resources which can be used in future dealings with political systems. ${ }^{64}$ Secondly, the relationships between the use of moderate behaviors and attaining responsive policies are weak. Certainly some types of militant behaviors can be effective under certain unspecified conditions. Thirdly, the conclusions in this paper must be deemed tentative pending the use of more rigorous sampling and measurement techniques.

Despite these limitations, the analysis has suggested a number of important conclusions. First, the policy response of community officials to protest-group demands is affected by both social support variables and protester-controlled variables. Although the environment of social support is more highly related to policy responsiveness than are protester-controlled variables, the conclusion that protest groups are therefore unable to influence policy responsiveness is avoided. Partly because protester-controlled variables have an independent effect on responsiveness and partly because protestercontrolled variables can affect the environment of social support, it has been argued that protest groups can enhance responsiveness by adopting appropriate behaviors. Secondly, the environment of social support which affects the policy response of local political systems to protest-group demands includes many more sectors of the community than simply its active groups. In particular, the attitudes of the targets of local protest-agency officials and elected officials-are more important determinants of policy responsiveness than is suggested by prevailing theories about protest groups. The implication is that protest groups can profitably appeal directly to

${ }^{64}$ In this regard, militancy may serve important expressive functions that are reinforcing to protest-group constituents and therefore keep them active in political organizations even if the policy outcome itself is not reinforcing. These ideas are suggested in the work of Robert H. Salisbury, "An Exchange Theory of Interest Groups," Midwest Journal of Political Science, 13 (February 1969), 1-32; and Mancur Olson, Jr., The Logic of Collective Action (rev. ed.; New York: Schocken Books, Inc., 1971). 
protest targets as well as to "third parties." Finally, the analysis has indicated that nonmilitancy may in general enhance both social support and policy responsiveness. Thus the effectiveness of militancy may be overestimated by some scholars and activists. 